\title{
Evaluation of Tax Regulations About Debt Equity Ratio Instrument to Prevent Thin Capitalization in Relation to Investment and Tax Revenue Policy in Indonesia
}

\author{
Chairil Anwar Pohan ${ }^{1}$, Karina Duwanty ${ }^{2}$, Pebriani Arimbhi ${ }^{3}$ \\ \{anwar_phn@yahoo.com ${ }^{11}$ karinaduwanty@gmail.com², pebriana@stiami.ac.id ${ }^{3}$ \} \\ Institut Ilmu Sosial dan Manajemen Stiami, Jakarta, Indonesia ${ }^{1,2,3}$
}

\begin{abstract}
The government is aggressively preventing companies from tax evasion, one of which is by setting a debt to equity ratio. Many observers claim that such an arrangement is recognized as being able to counteract Thin Capitalization. However, if it is related to the investment policy in Indonesia, it seems that it is still not synergistic. This study aims to analyze the adequacy of the effectiveness of the application of taxation policies on the debt equity ratio instrument in counteracting the practice of thin capitalization in Indonesia and how the tax policy on the debt equity ratio instrument is linked to investment policies in Indonesia. This research approach is a qualitative approach with descriptive methods. The results of the study conclude that the application of taxation policies on the debt equity ratio instrument is quite effective in counteracting the practice of thin capitalization in Indonesia, the taxation policy on the debt equity ratio instrument indirectly affects investment policy in Indonesia, and there are still ratio constraints in implementing taxation policies on equity instruments. debt. Efforts to be able to overcome the obstacles that occur with appropriate socialization, education, supervision and inspection of taxpayers so that tax revenues can be optimal.
\end{abstract}

Keywords: Debt Equity Ratio, Thin Capitalization, Investment Policy, Tax Revenue in Indonesia.

\section{Introduction}

The increasing development of information technology and the more open economy of a country will certainly provide opportunities for companies to develop their business by creating various innovations in goods and services. As a profit-oriented company, of course, a company will try to get as much profit as possible through various kinds of cost efficiency, including the efficiency of the tax burden. The government also made various efforts to attract foreign investors to be interested in investing in Indonesia by providing investment allowances and tax holidays and building infrastructure in various development sectors in urban and regional centers. In the context of international taxation, there are several modes commonly used by multinational companies to carry out tax avoidance or tax savings, namely with the scheme i. Transfer pricing, ii. Thin capitalization, iii. Treaty shopping, and iv. Controlled foreign corporation (CFC). (Pohan, 2018: 421).

Related to the above matters, namely the increasingly sophisticated financial transaction schemes that exist in the business world certainly will also create opportunities for companies to carry out tax avoidance transaction schemes in order to reduce their tax burden, especially if there is a vacuum of legislation - invitation to these tax avoidance schemes. For companies 
that operate internationally (international companies) the opportunity to conduct tax avoidance is more open, namely by utilizing differences in a country's tax system (international tax avoidance). In international trade, multinational companies have a role of 60 percent of international transactions.

Regarding foreign direct investment [hereinafter referred to as FDI (PMA)] of multinational companies, in 2005 the investment realization from FDI (PMA) was estimated to reach US $\$ 8.68$ billion or an increase of $88.69 \%$, an increase of two times from the previous year of US $\$ 4.60$ billion. Seeing the large amount of foreign investment entering Indonesia, government revenues derived from multinational corporate taxes should be high. However, we were shocked by the statement of the former Finance Minister Bambang Brodjonegoro that there were around 2,000 companies categorized as FDI (PMA), which had not paid taxes in the past 10 years. The company is divided into many sectors. The reason that is always conveyed to the Directorate General of Taxes (DGT) is that the company loses. But the reality is different from the results of the DGT calculation and examination, where according to tax calculations or checks, the company should pay an average of Rp. 25 billion a year. The FDI (PMA) is trying to avoid taxes or conduct tax evasion which is usually done by companies in Indonesia, with various modes such as transfer pricing through shareholder loans.

Increasing the domestic revenue target from the tax sector is reasonable, because logically the amount of tax payments from year to year is expected to increase in line with the increase in population and public welfare. In performing tax payment obligations, taxpayers must carry out tax planning. In planning the tax, companies utilize the regulations available to minimize their tax payments. This is done so that taxpayers can pay taxes as efficiently as possible in accordance with applicable provisions (Rimsky, 1999).

From the economic aspect, the Debt Equity Ratio (DER) shows the company's ability to finance its company with its own capital to fulfill all its obligations, besides being used to measure financial / economic health from the company's capital structure used by third parties, such as banks, investors/candidates investors to provide one of the considerations in the feasibility of providing bank credit, additional capital disbursement, but in terms of taxation, the determination of DER is used for tax calculation purposes, and this ratio provides opportunities which can be an effort to conduct tax avoidance in tax planning carried out by investors.

The debt equity ratio is used as a measure of thin capitalization. To measure to what extent the company's assets are financed by debt to show indications of the level of security of lenders (banks), the debt equity ratio (DER) is one measure of corporate financial leverage calculated by dividing total liabilities with stockholders equity, which indicates what proportion of equity and debt are used by companies to finance their assets. The use of this debt equity ratio in addition to taxation purposes can be used to maintain the condition of liquidity, solvency and profitability of the company.

The thin capitalization by increasing debt is an attempt to transform payments to investors for dividend income from equity income because of double taxation (income tax on profits and dividends), becoming interest income from loans that are only charged once. Debt financing practices provide more tax savings.

Basically thin capitalization is the engineering of the formation of a capital structure where the amount of debt is far greater than the number of shares. Why is this attractive thin capitalization raised to the surface at the level of tax assessment? First, because the new debt equity ratio rules related to thin capitalization will increase the burden of many taxpayers and can become an additional barrier for new investors in Indonesia. Secondly, 
because there is a significant difference in the tax treatment between the withdrawal of debt and equity funds, where the provisions of taxation allow payment of interest on loans as a tax deduction, whereas payment of dividends on shares cannot be a tax deduction. As a result of the difference in tax treatment between interest and dividends, companies that increase their debt thus increase loan interest payments and will mean reducing the tax that must be paid. Third, it is suspected that there are many foreign investors in Indonesia, who finance the operations of their companies, preferring to prioritize loans (equity) due to the disparity in tax treatment that is more profitable interest (loan capital benefits) as a deduction from debtor taxable income than dividend (equity income), so that the thin capitalization action can reduce tax revenue.

In further development, the government through the Minister of Finance Decree number 1002 / KMK.04 / 1984 dated October 8, 1984 issued a decree concerning the determination of the ratio between debt and own capital for the purposes of income tax wherein Article 1 states that for the calculation of income tax the amount of comparison between debt and equity (debt equity ratio) set as high as three compared to one (3: 1). In article 2 paragraph (1) mentioning the debt referred to above is the average balance at the end of each month calculated from all debts, both long-term debt and short-term debt, in addition to trade payables. And article 2 paragraph (2) states that the capital as referred to in article 1 is the amount of paid-up capital at the end of the tax year including profits that are not and / or have not been distributed.

However, the debt equity ratio policy did not last long, because the government changed its regulations, on the basis that the determination of the ratio between debt and own capital for general and applicable Income Tax imposition was feared to hinder the development of the business world. implementation of Decree of the Minister of Finance of the Republic of Indonesia Number: 1002/KMK.04/1984 dated October 8, 1984 with the issuance of Decree of the Minister of Finance number 254/KMK.01/1985 dated March 8, 1985, suspended until the date determined later by the Minister of Finance.

Since then there has been a vacuum in tax regulations regarding the debt equity ratio until the issuance of the Minister of Finance regulation No.169/PMK.010/2015 dated 09 September 2015 (then abbreviated PMK-169/2015) concerning the determination of the ratio between debt and corporate capital for the purposes of calculating income tax, which came into force since 2016 tax. In the regulation it is stated that for the purposes of calculating Income Tax the amount of debt and capital is determined for taxpayers of entities established or domiciled in Indonesia whose capital is divided into shares. One thing that is considered logical and reasonable for foreign investors who always make every penny they invest in each business unit or subsidiary abroad at the level of the minimum subsidiary tax burden so that the profit contribution to its parent company abroad is maximal, so the parent company is more likely choose to give a loan rather than increase the deposit of capital. The new Minister of Finance policy has provided leeway for foreign investors to provide loans to their affiliated companies in Indonesia with a maximum DER limit of 4: 1. However, is the 4: 1 ratio specified in PMK$169 / 2015$ appropriate? The answer is relative. When compared with the average in other countries, which is 3: 1 , it looks like PMK-169/2015 provides concessions that provide taxpayers with room to have larger loans in their capital structure. It seems that the government wants to have provisions that also do not hamper business expansion, as it was once the reason for suspension of KMK-1002/1984. However, there is no certainty about valid reasons and considerations regarding this $4: 1$ number.

According to B. Bawono Kristiaji of Dany Darussalam Tax Center (2015: 9), the absence of a quantitative study of the ratios deemed appropriate can have considerable implications 
later on. Especially regarding the number of companies that are likely to exceed the 4: 1 DER limit and the implications for financing their business expansion.

Table 1. Comparison of Capital Structure and Debt in Tbk Companies Registered on the Stock Exchange in 2012 Up to 2016

\begin{tabular}{|c|c|c|c|c|c|}
\hline No & Company & Ekuitas & Liabilities & $\begin{array}{c}\text { Rasio } \\
\text { DER }\end{array}$ & Tahun \\
\hline 1 & PT. Argo pantes Tbk & $439,121,274.00$ & $4,107,964,851.00$ & 9.35 & $2012-2016$ \\
\hline 2 & PT. Century Textile Industry Tbk & $10,692,409.00$ & $146,226,367.00$ & 13.68 & $2012-2016$ \\
\hline 3 & PT. Ever Shine Tex Tbk & $52,685,043.00$ & $166,982,979.00$ & 3.17 & 2014-2016 \\
\hline 4 & PT. Eratex Djaja Tbk & $8,989,240.00$ & $35,831,330.00$ & 3.99 & 2012 \\
\hline 5 & PT. Panasia Indo Resources Tbk & $604,865,227.00$ & $3,619,720,129.00$ & 5.98 & 2014 \\
\hline 6 & PT. Ricky Putra Globalindo Tbk & $390,263,218,936.00$ & $781,749,249,068.00$ & 2.00 & 2014 \\
\hline 7 & PT. Sunson Textile Manufacturer tbk & $258,131,240,475.00$ & $515,532,106,459.00$ & 2.00 & 2014 \\
\hline 8 & PT. Indo-Rama SyntheticsTbk & $1,499,403,041.00$ & $2,353,700,907.00$ & 1.57 & $2012-2016$ \\
\hline 9 & PT. Agung Podomoro Land Tbk & $41,034,599,298.00$ & $67,797,818,258.00$ & 1.65 & $2012-2016$ \\
\hline 10 & PT. Alam Sutera Realty Tbk & $30,225,108,105.00$ & $50,969,759,468.00$ & 1.69 & $2012-2016$ \\
\hline 11 & PT. Island Concepts Indonesia Tbk & $22,337,691,875.00$ & $61,025,761,986.00$ & 2.73 & 2012 \\
\hline 12 & PT. Grahamas Wisata Tbk & $7,010,712,514.00$ & $32,828,298,602.00$ & 4.68 & 2016 \\
\hline 13 & PT. Panorama Sentrawisata Tbk & $413,248,542.00$ & $1,332,732,675.00$ & 3.23 & 2015 \\
\hline 14 & PT. Destinasi Tirta Nusantara Tbk & $849,939,001,315.00$ & $868,130,644,420.00$ & 1.02 & $2012-2016$ \\
\hline 15 & PT. Unilever Indonesia Tbk & $4,704,258.00$ & $12,041,437.00$ & 2.56 & 2016 \\
\hline 16 & PT. Tri Bayan Tirta Tbk & $542,329,398,166.00$ & $960,189,991,593.00$ & 1.77 & 2013 \\
\hline
\end{tabular}

Source of data: www.idx.co.id

Based on table 1., it is clear that quite a number of Tbk (go public) companies where the company's total debt is far greater than the amount of capital deposited and this indicates that the company has been aggressive in financing growth with debt. This can result in earnings volatility as a result of additional interest expenses. Conversely, if a lot of debt is used to finance operations (high debt to equity), the company has the potential to generate more income than that without external financing. If there is an increase in income with a larger amount than the cost of debt (interest), then the shareholders will get a profit as income distributed to the shareholders proportionally. However, this debt financing may be greater than the company's revenue generated from debt through investment and business activities and becomes too large for the company to carry the burden. This can lead to bankruptcy of the company, which will cause shareholders to get nothing.

The phenomenon that the authors raise in this study is that there is an indication that the country has the potential to experience losses from tax revenues on loans from foreign investors / creditors by providing concessions to the Debt Equity Ratio which in turn gives investors a wider scope for tax evasion. Meanwhile, the looseness of the debt equity ratio is indicated not in line with investment policies of the Investment Coordinating Board so that investors invest their capital in the form of stock investments rather than in loans.

This research will be focused on evaluating tax regulations regarding the Debt Equity Ratio instrument in practice, the ability of the DER instrument to counteract Thin Capitalization and how the DER instrument can be used to target the amount of investment as well as tax revenue in Indonesia. 
The research objectives are: (1) To analyze the adequacy of the effectiveness of the implementation of tax policy on instruments of debt equity ratio in counteracting the practice of thin capitalization in Indonesia. (2) To analyze the extent to which tax policies on debt equity ratio instruments are in line with investment policies in Indonesia. (3) To analyze the inhibiting entities in implementing the debt equity ratio policy to counteract the practice of thin capitalization in Indonesia. (3) To analyze the driving entities in the implementation of the debt equity ratio policy to counteract the practice of thin capitalization in Indonesia.

Referring to the research objectives above, this research is expected to provide benefits, for improving services at BKPM and Jakarta Foreign Investment One Tax Office which of course have an impact on investors in fulfilling their tax obligations, and also expected to help the government to further evaluate the policies of the Minister of Finance Regulation No. 169/ PMK.010/2015 on September 9, 2015 in terms of the flexibility of the Debt Equity Ratio.

\section{Thinking Framework}

Taxes for companies are considered a burden, so certain efforts or strategies are needed to reduce them. The strategy that is done is tax avoidance is an effort to reduce tax debt that is legal in nature by complying with existing rules. Thin capitalization is a way to engineer the formation of a capital structure where the amount of debt is far greater than the number of shares. because the new debt equity ratio rules related to thin capitalization will increase the burden of many taxpayers and can become an additional barrier for new investors in Indonesia.

In the discussion of thin capitalization the author uses the thin capitalization indicator from Larry Crumbley (1994: 306), namely (1) initial capitalization is made thin, (2) shareholders can provide loans to companies, (3) shareholders can borrow loans from outside. Based on the Income Tax Act Article 18 paragraph 1, it is stated that the Minister of Finance has the authority to issue a decision on the size of the ratio between debt and capital of the company that can be justified for the purposes of tax calculation. Determination of the size of the ratio between debt and own capital has been regulated as of October 8, 1984 with the enactment of the Minister of Finance Decree Number 1002/KMK.04/1984 concerning the Comparison of Debt and Own Capital for the Purposes of Income Tax Imposition set at a maximum of three compared to one (3: 1). However, only five months later, on March 8, 1985, a Decree of the Minister of Finance of the Republic of Indonesia (PMK) No. 254/KMK.01/1985 was issued which contained the suspension of the Decree of the Minister of Finance of the Republic of Indonesia Number: 1002/KMK.04/1984 on the grounds that the comparison between debt and own capital for general and general income tax imposition is feared to hinder the development of the business world. The deferral of the intention turned out to require a very long time, namely more than 10 years, precisely on 9 September 2015, the Regulation of the Minister of Finance of the Republic of Indonesia Number (PMK) No. 169/PMK.010/2015 was stipulated concerning Determination of the Comparison Between Debt and Company Capital for the Calculation of Income Tax Calculation the highest is four compared to one (4: 1) and applied since the 2016 tax year. Given the importance of the rules regarding the amount of the Debt Equity Ratio to prevent the practice of thin capitalization which is detrimental to state revenues from the tax sector, many countries regulate the size of the Debt Equity Ratio the provisions of thin capitalization rules in their country combined with ownership requirements. For example, Japan limits the 3: 1 DER with terms of ownership of more than 50\%, Australia also limits the 3: 1 DER ratio but ownership is lower at 15 percent and Canada more tightly limits the 2: 1 DER ratio with terms of ownership up to 25 percent. 
The practice of tax policy on debt equity ratio instruments is still considered to be unable to counteract the practice of tax avoidance in Indonesia because the explanation in the income tax law is still very simple, so it still provides loopholes for taxpayers not to comply with the law.

The tax policy on the instrument of debt equity ratio is also considered to be still less synergistic with investment policy in Indonesia because when compared to other countries that set the DER average of 3: 1, PMK-169/2015 provides opportunities for investors to more choose to give a loan rather than investing their shares in Indonesia.

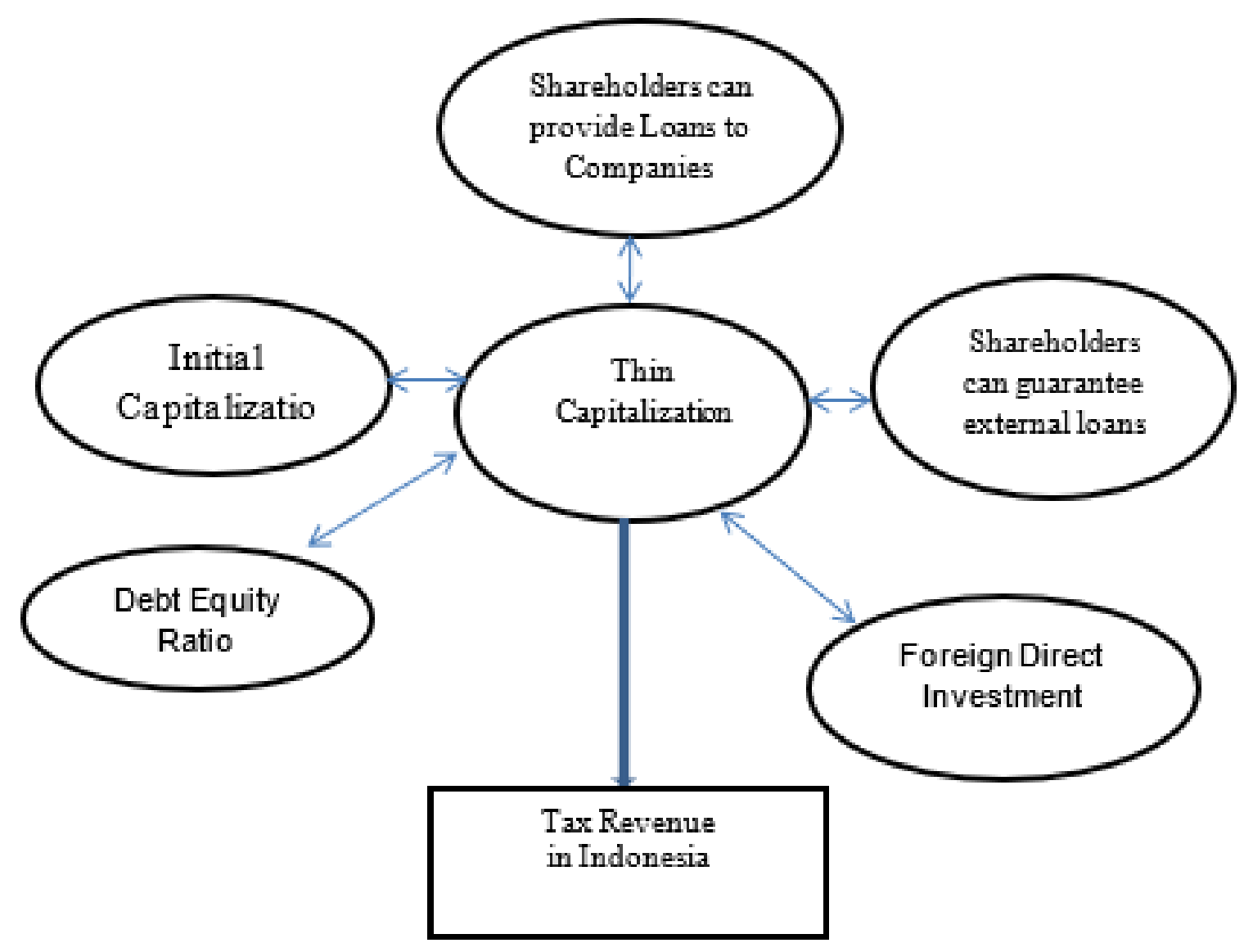

Figure 1. Flow Chart of Thinking Framework Picture-1 


\section{Conceptual Model}

\begin{tabular}{|c|c|}
\hline $\begin{array}{l}\text { 1. Ning Rahayu (2010: 61) } \\
\text { University of Indonesia } \\
\text { Research Title: } \\
\text { Regulatory Evaluation of } \\
\text { Foreign Investment Tax } \\
\text { Avoidance Practices } \\
\text { The data used in this study are } \\
\text { primary data namely data } \\
\text { obtained from interviews and } \\
\text { observations. The method used } \\
\text { is a qualitative method. } \\
\text { Source: Joumal of Indonesian } \\
\text { Accounting and Finance, Vol.7, } \\
\text { No.1 (2010) }\end{array}$ & $\begin{array}{l}\text { The results of the study show that very common tax } \\
\text { avoidance practicas are carried out through transfer } \\
\text { pricing schemes and thin capitalization. Both schemes } \\
\text { have been used in such a way as to provide optimal } \\
\text { benefits from loopholes in tax regulations. And, we } \\
\text { identify the existence of govemment anti-tax } \\
\text { avoidance regulations in terms of a good regulatory } \\
\text { process that is far from perfect, in fact the prevailing } \\
\text { regulations and regulations are still in anticipation of } \\
\text { tax evasion efforts by taxpayers. For this reason, the } \\
\text { Govemment cannot obtain optimal tax income from } \\
\text { taxpayers. Furthermore, Indonesia anti-tax } \\
\text { avoidance policies still lag behind the latest isaues of } \\
\text { tax avoidance practices that are increasingly complex } \\
\text { and difficult to detect. }\end{array}$ \\
\hline
\end{tabular}

\begin{tabular}{|c|c|}
\hline $\begin{array}{l}\text { 2. Ning Rahayu (2010: 179) } \\
\text { University of Indonesia } \\
\text { Research Title: } \\
\text { Tax Avoidance Practices by } \\
\text { Foreign Direct Investment in the } \\
\text { Form of Foreign Investment } \\
\text { Limited Liability Company } \\
\text { Research Method: } \\
\text { The research approach chosen in } \\
\text { this study is a mixed approsch } \\
\text { combined to answer research } \\
\text { questions that cannot be fully } \\
\text { answered by qualitative or } \\
\text { quantitative approaches. The } \\
\text { data used in this study are } \\
\text { primary data, namely data from } \\
\text { the results of in-depth } \\
\text { interviews. }\end{array}$ & $\begin{array}{l}\text { The results showed that tax avoidance practicas, } \\
\text { which were generally carried out by the Foreign } \\
\text { Direct Investment (FDI) in the form of subsidiary } \\
\text { companies (PT. PMAA) in Indonesia, were carried out } \\
\text { through transfer pricing schemes, thin capitalization, } \\
\text { Controlled Foreign Corporation (CFC), utilization of } \\
\text { tax haven and treaty shopping countries. The most } \\
\text { widely used tax avoidance schemes in Indonesia are } \\
\text { transfer pricing achemes, thin capitalization and treaty } \\
\text { shopping. Then, the practice of tax avoidance is } \\
\text { carried out by utilizing the opportunities contained in } \\
\text { the applicable tax provisions. This is also reinforced } \\
\text { by the characteristics of the relationship between } \\
\text { subsidiary companies in Indonesia with parent } \\
\text { companies abrosd which according to the tax } \\
\text { perspective are considered as separate entities. Thus, } \\
\text { between the subsidiary and the parent company, it can } \\
\text { conduct inter-company transactions arranged in such a } \\
\text { way that the subsidiary company in Indonesia suffers } \\
\text { a loss, while the overall business other than in } \\
\text { Indonesia is still profitable. }\end{array}$ \\
\hline
\end{tabular}




\begin{tabular}{|c|c|}
\hline $\begin{array}{l}\text { Source: Joumal of Public } \\
\text { Administration, Vol. 10, No. } 2 \\
(2010)\end{array}$ & \\
\hline $\begin{array}{l}\text { 3. Richard Pardomuan } \\
\text { Parulian Siahaan (2010: } \\
\text { 100) University of } \\
\text { Ind onesia } \\
\text { Research Title: } \\
\text { Analysis of Anticipating Thin } \\
\text { Capitalization Practices in } \\
\text { Indonesia } \\
\text { Research Method: } \\
\text { The approach of this research is } \\
\text { a qualitative approach. The type } \\
\text { of research used in this study is } \\
\text { descriptive anslysis. Data } \\
\text { collection methods used in this } \\
\text { study are library studies and } \\
\text { field studies. } \\
\text { Sources of thesis: Richard } \\
\text { Pardomuan Parulian Siahsen, } \\
\text { June 2010, Faculty of Social and } \\
\text { Political Sciences, University of } \\
\text { Indonesia, p. } 100 \text {. }\end{array}$ & 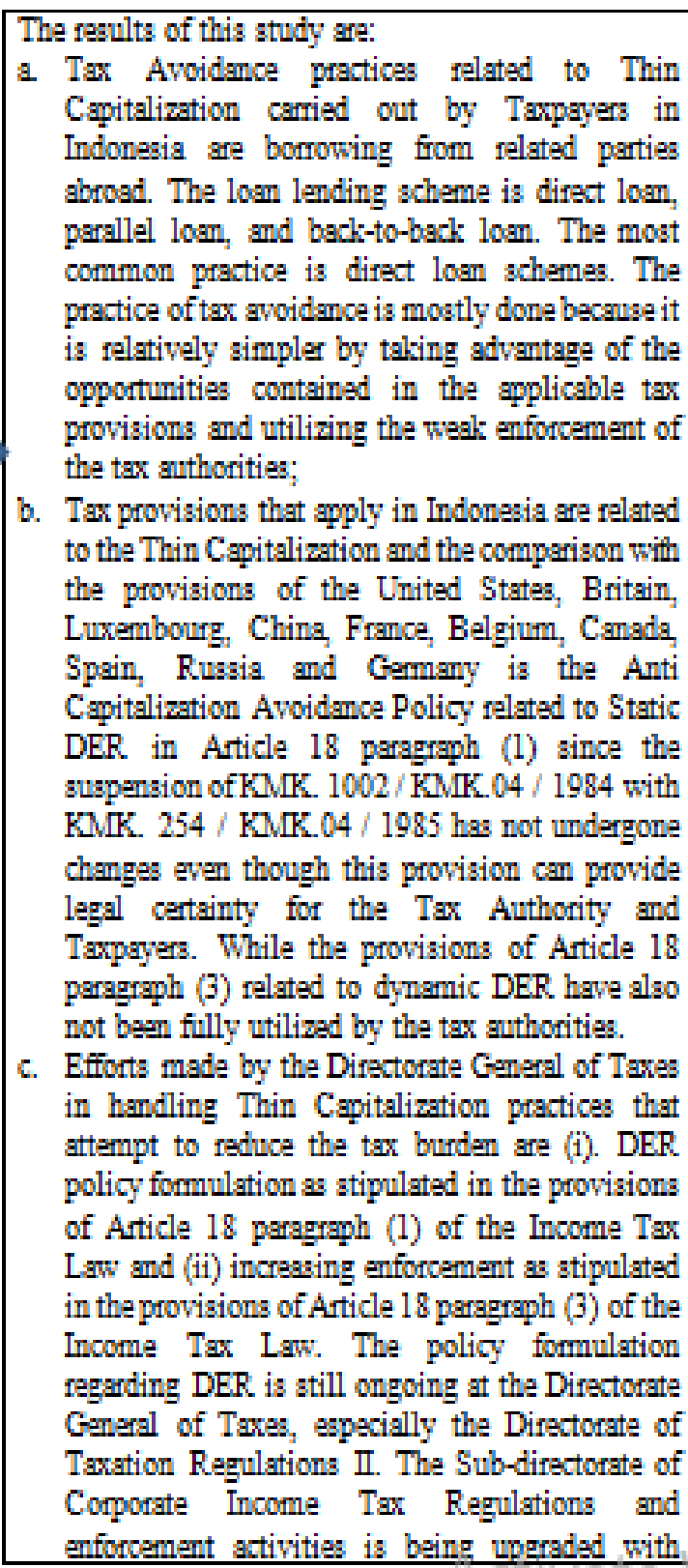 \\
\hline
\end{tabular}




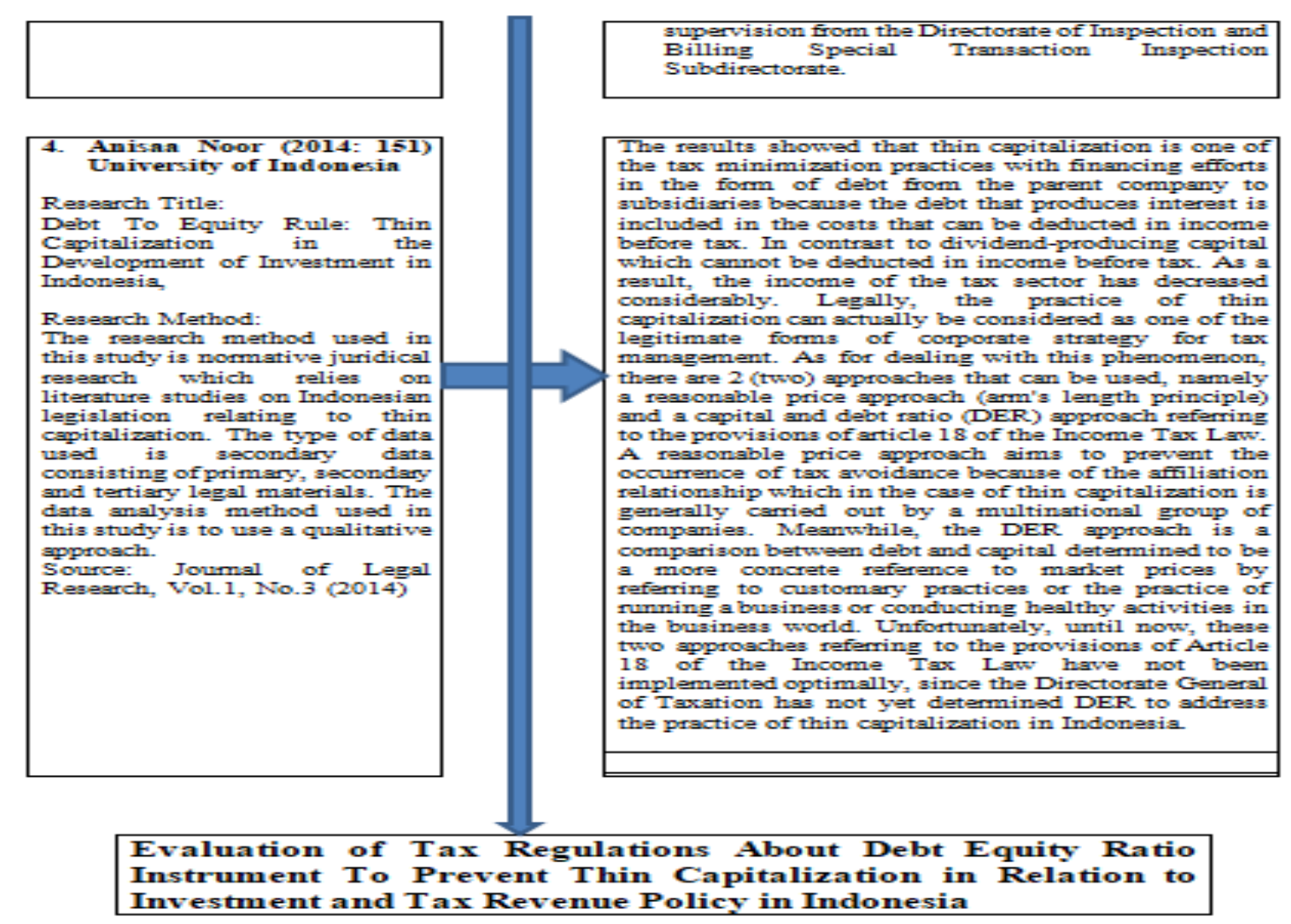

Figure 2. Conceptual Model

\section{Research Methods}

The data analysis method used in this study is descriptive analysis method by applying comparative research. While the research approach used is a qualitative approach. According to Creswell (2014: 4), "an inquiry process of understanding a social or human problem, based on building a complex, holistic picture, formed with word, detailed reporting of information and conducted in a natural setting." A qualitative approach applies a paradigm naturalistic, where research is carried out in natural settings. In this qualitative research method, the research method is used to examine natural object conditions, where the researcher is a key instrument, the technique of data collection is triangulated (combined), data analysis is inductive, and the results of qualitative research emphasize the meaning rather than generalization. The research dimension is a case study, in the sense of conducting a study of one social reality. In this study, researchers applied a case study that was examined from various aspects as well as strategies to obtain the data in question. Qualitative data is in the form of in-depth interviews, observations, literature studies and documentation, but it is also possible to use quantitative data as a complementary information on each research analysis question. Data Collection Techniques use: 1. Literature Study in the form of oil and gas statistical data, scientific publications in journals, papers and articles. 2. In-depth, opened ended interviews: to strengthen the results of analysis and discussion, the author also 
conducted in-depth interviews with informants namely, Mr. August Andrian as Person in charge with Advance Pricing Agreement/Mutual Agreement Procedure Analyst of the Directorate General of Taxes as Informant 1; Mr. Yohanes Bambang Account Representative of the Service Office Tax One Foreign Investment as informant 2; Ms. Maria S. Rahardjo, the Head of the Secondary Sector Section -Deregulation Directorate at Investment Coordinating Board as informant 3; Mr. Ganda Christian Tobing., LL.M Int. Tax Senior Manager at Tax Advisory and Litigation Services of Danny Darussalam Tax Center as informant 4; Ms. Lisayanti Lie, Certified Tax Consultant as informant 5; Mr. Yustinus Prastowo, Director of Center For Indonesia Taxation Analysis as informant 6; Mr. Agus Budi Waluyo, Certified Tax Consultant and Taxation Lecturer as informant 7. Mr. B. Bawono Kristiaji, Tax Senior Manager of Danny Darussalam Tax Center as informant 8.

\section{Research Result and Discussion}

Results of interviews with few informants :

1. Evaluate the implementation of tax policies on instruments of debt equity ratio in counteracting the practice of thin capitalization in Indonesia

The implementation of the tax policy on the instrument of debt equity ratio, which based on the Income Tax Act Article 18 paragraph 1 states that the Minister of Finance has the authority to issue a decision on the magnitude of the ratio between debt and company capital that can be justified for tax calculation purposes. Determination of the size of the ratio between debt and own capital has been regulated as of October 8, 1984 with the enactment of the Minister of Finance Decree Number 1002/KMK.04/1984 concerning the Comparison of Debt and Own Capital for the Purposes of Income Tax Imposition set at a maximum of three compared to one (3: 1). However, only five months later, on March 8, 1985, a Decree of the Minister of Finance of the Republic of Indonesia 254/KMK.01/1985 was issued which contained the suspension of the Decree of the Minister of Finance of the Republic of Indonesia Number: 1002/KMK.04/1984 on the grounds that the comparison between debt and own capital for general income tax imposition is feared to hinder the development of the business world. The deferral of the intention turned out to require a very long time, namely more than 30 years, precisely on 9 September 2015, PMK-169/2015 was stipulated concerning Determination of the Comparison Between Debt and Company Capital the highest of four compared to one (4: 1) and applied since the 2016 tax year. In evaluating the Implementation of Tax Policies About the Debt Equity Ratio Instrument in Counteracting Thin Capitalization In Indonesia, researchers studied using Thin Capitalization indicators from Larry Crumbley, namely: Debt Equity Ratio, Initial Capitalization Is Made Thin, Shareholders Can Provide Loans To Companies, Shareholders Can Guarantee External Loans, Foreign Direct Investment. Dimensions Evaluation of the implementation of tax policy on instrument debt equity ratio in counteracting the practice of thin capitalization can be described as follows:

\section{a. Debt Equity Ratio}

The author argues that the implementation of tax policy on debt equity ratio instruments is intended as an effort to counteract the practice of thin capitalization in Indonesia, where this provision has been quite effective considering the only 
provisions used to counteract thin capitalization in Indonesia after a long time this regulation has been suspended and just returned to effect. Efforts made by the tax authorities through the dissemination of this policy are often carried out.

According to Mr. August Andrian (Informant 1), that previously in 1984 the policy of DER 3: 1 had been regulated but in 1985 a letter was issued to suspend the policy due to consideration of a business climate that did not support. Until 2015, the new DER 4: 1 policy was reissued, where if it is benchmarked to other countries this is a provision that is very familiar and generally applied. Highlighting countries that we do benchmarks still use fixed ratio basis DER. When viewed from benchmarks in other countries the provisions of the debt equity ratio are currently the most effective because only the only regulation to counteract thin capitalization is proven by its sustainability and the results may not necessarily be the same as new alternatives that exist later.

According to Mr. Yohanes Bambang (Informant 2), that it was quite effective in counteracting thin capitalization in Indonesia, tax policy on debt equity ratio instruments issued by the government through PMK-169/2015 concerning Determination of the ratio between Debt and Company Capital for the purposes of Income Tax Calculation, the amount of the ratio between debt and capital is set at a maximum of four to one (4: 1) and based on article 7 of this PMK-169/2015 comes into force since 2016 Tax Year. So for companies that still have a debt and capital ratio of more than $4: 1$, it will have an impact on the positive correction of the loan interest charged.

According to Ms. Maria S. Rahardjo (Informant 3) that the implementation was still less effective in counteracting thin capitalization, because investors were also still hesitant to invest too much in Indonesia, especially when viewed from DER 4: 1 they definitely prefer to deposit their capital with the minimum and make a loan for the next.

According to Mr. Ganda Dua Christian Tobing (Informant 4), that in its implementation it was still not effective in counteracting thin capitalization, the practice of thin capitalization could be prevented by limiting the imposition of interest fees based on a certain percentage of EBITDA. Let's look more broadly at the horizon of thinking in the world of taxation globally. I refer to the Base Erosion and Profits Shifting (BEPS) Project which was initiated by countries that are members of the OECD and G20. Indonesia as a member of the G20 supports this BEPS Project. One of the Action Plans in the BEPS Project, namely the Action Plan 4 related to limitation of interest deduction, recommends that the practice of imposing excessive interest costs be prevented by rules in the form of restrictions based on a certain percentage of EBITDA. In many countries, such as Germany, the regulation on the imposition of interest charges adopted in its tax regulations is a certain percentage of EBITDA. Many countries have abandoned the use of the provisions of the debt equity ratio in an effort to counteract the practice of thin capitalization. The trend in taxation rules in many countries related to the limitation of charging interest is by applying a certain percentage of EBITDA.

According to Ms. Lisayanti Lie (Informant 5), that the provisions of the most effective Debt Equity Ratio to ward off thin capitalization, tax avoidance in subsidiaries of multinational companies ", while Mr. Agus Budiwaluyo (Informant 7) stated that the provisions of Debt Equity The ratio has been effective to counteract thin capitalization. 


\section{b. Initial Capitalization Is Made Thin}

According to the author that in order to invest in Indonesia, investors must follow the terms and conditions made by the Investment Coordinating Board (hereinafter refer to as BKPM) so that the investment submission process can be approved and does not violate existing provisions.

Based on the results of the interview, the researchers found similar opinions between informant 1 , Informant 2 , informant 3 , informant 4 , informant 5 , and informant 6 regarding the minimum capital of investment for FDI (PMA), that FDI itself was regulated in Article 13 paragraph (3) BKPM Regulation 14/2015 for a total investment value of more than Rp.10,000,000,000.00 (ten billion rupiahs), excluding land and buildings and for the value of capital placed equal to paid up capital, at least Rp.2,500,000,000.00 (two billion five hundred million rupiah).

\section{a. Shareholders Can Provide Loans to Companies}

According to the author, the deposit of capital with a minimum deposit is one of the methods used by investors so that investors can provide loans to companies rather than providing additional capital, due to the real difference in treatment between debt and capital.

Based on the results of the interview, the researchers found similar opinions between informant 1 , Informant 2 , informant 3 , informant 4 , informant 5 , informant 6 and 8 , that the capital deposit with the minimum limit was intended so that foreign investors could lend to the company rather than providing additional capital with consideration if you give a loan you can still get interest even if the company loses while if you give additional capital you can only get dividends if you get profit.

\section{d. Shareholders Can Guarantee External Loans}

According to the authors the ratio of debt and capital ratio 4: 1 does not guarantee that shareholders can guarantee external loans because investors see business prospects, while investors see dividend prospects. The DER 4: 1 policy is intended for companies that often charge loan interest fees with unreasonable limits to be covered while limiting the extreme interest costs, the policy as a government effort to increase the target and realization of tax revenues.

Based on the results of the interview, the researchers found similar opinions between informant 1 , Informant 2 , informant 3 , informant 4 , informant 5 , and informant 6 and 8, that although shareholders could guarantee external loans, DER 4: 1 did not guarantee investors could obtain loans from overseas.

\section{e. Foreign Direct Investment}

According to the author, the tax policy on debt equity ratio instruments is not able to attract foreign investors to invest in Indonesia due to the concession provided by the Minister of Finance regarding the ratio of debt and capital which is a little more loose namely 4: 1 , giving investors more loans than deposits capital. And taxation policies on debt equity ratio instruments have an effect on investment but indirectly. This author's opinion was published by Mr. August Andrian (Informant 1), Mr. Yohanes Bambang (Informant 2), Ms. Maria S. Rahardjo (Informant 3) and Mr. Agus Budiwaluyo (informant 7), they explained that "If viewed regionally it might be one factor to attract investors, but this provision is not possible. When viewed from DER 4: 1 , which is looser than other countries, he is sure to go to Indonesia." 
The same opinion was expressed by Mr. Ganda Christian Tobing (Informant 4) and Ms. Lisayanti Lie (informant 5) who explained that "Investment decisions are not only influenced by tax factors. There are still many other factors that influence the decision to invest."

\section{Analysis of Tax Policy About Debt Equity Ratio Instruments in Relation to Investment Policies in Indonesia}

According to the author, the tax policy on debt equity ratio instruments has a direct influence on investment in Indonesia, recalling that the size of the ratio between debt and capital is looser, namely 4: 1, making investors prefer loans rather than additional capital deposits where the real treatment of differences between debt and capital.

In applying tax policy on debt equity ratio instruments according to informant 1 , and informant 2 , informant 3 , informant 4 , informant 5 , and informant 6 there is an association with investment policy in Indonesia but indirectly and this DER provision seeks not to close investors to invest in Indonesia.

3. Inhibiting Entities in the Implementation of the Debt Equity Ratio Policy to Prevent Thin Capitalization Practices in Indonesia

The author argues that in the implementation of the debt equity ratio policy to ward off thin capitalization in Indonesia there are internal and external obstacles faced by the Directorate General of Taxes based on interviews, namely internal barriers are questions regarding PMK-169/2015 why set at 4: 1 or more loose from the previous regulations and why this regulation after a long time has been re-established, and the socialization has not been carried out optimally so that it needs more education about this regulation.

According to Mr. August Andrian (Informant 1) that the internal constraints were in the form of questions related to PMK-169/2015 why not smaller or so, why should it be 4: 1 because later deductible costs are greater etc. Communication constraints as to why this change occurred and why is it only now, it needs socialization as well where the stages of introducing the new regulations need more education. As for external obstacles are education and knowledge of taxpayers to report debt and capital positions, and how they complain.

According to Mr. Ganda Christian Tobing (Informant 4) that the current debt-equity ratio policy is not in accordance with the objectives of the regulation. In practice, it is easy to determine taxpayers who must apply the rules of debt-to-equity ratio so that it tends to be easier for authorities to withdraw tax deposits, while it is unfair for taxpayers if the size used is a debt-to-equity ratio and besides high compliance costs indicated by the obligation to report debt-to-equity ratio and reporting of foreign debt to the tax authority.

According to Ms. Lisayanti Lie (informant 5), that the constraints for companies are small (small) PTs whose micro and small-scale enterprises (MSMEs) rely on bank loans and finance companies for their business activities. Added by Mr. Agus Budiwaluyo (Informant 7) that the obstacles must be seen from most companies in Indonesia "If you want to apply this DER scheme to all businesses there may be many companies that object because most companies in Indonesia are MSMEs. Even though MSMEs must get protection, including, of course, from tax payments that are not burdensome, because if you apply this regulation the interest costs will decrease and of course taxes will increase". 
From the results of the interview above the authors conclude that the obstacle in implementing the debt equity ratio policy to counteract the practice of thin capitalization in Indonesia is the socialization of tax authorities, education, and the implementation of the current debt-equity ratio policy that is not in accordance with the objectives of its regulation.

\section{Driving Entities in the Implementation of the Debt Equity Ratio Policy to Prevent Thin Capitalization Practices in Indonesia}

According to the author, the implementation of tax policy on instrument debt equity ratio to ward off thin capitalization in Indonesia will run smoothly and in accordance with its objectives if it is supported by honesty from taxpayers, good supervision, extensive socialization, and good cooperation between tax authorities and taxpayers.

According to Mr. August Andrian (Informant 1) that efforts to counteract thin capitalization only with PMK-169/2015. But efforts to improve compliance generally we do education, counseling, then an explanation of these rules.

According to Mr. Yohanes Bambang (Informant 2), that through education (by providing information on this rule), through a Request Letter Explanation of data and Clarification to taxpayers who have a ratio above 4: 1 , and are encouraged to make corrections to the Annual Income Tax Return if the interest on the loan has not been made a positive correction, and conduct an examination of the taxpayer who has not calculated correctly and does not conduct self assessment.

According to Ms. Maria S. Rahardjo (Informant 3) that if we see the DER at the beginning of the investment when she has developed whether she is expanding her business or what is her name the source of the gift from the return is planted again, so that he can retain his debt not much, using company profits we call it reinvested profits, so the source of financing is in addition to own capital, loans, and profits are planted but this is not new because there is no profit yet.

According to Mr. Ganda Christian Tobing (Informant 4) that for the tax authorities is the expansion of checks and the increase in tax deposits and the fulfillment of targets. For taxpayers, the tax deposit is increasing due to tax regulations governing financial health measures that are not in accordance with financial health measures that are generally understood in the business world. The tax costs are increasing so that the business world is increasingly bleeding to continue to exist while still complying with tax strangulation.

According to Ms. Lisayanti Lie (informant 5) that because some companies avoid Income Tax by giving loans to companies rather than making additional capital. By lending to the company, the costs associated with the loan can be financed (reducing income).

According to Mr. Agus Budiwaluyo (Informant 6) that the business burden is closer to reasonableness because it means that the capital structure and debt are more rational, encouraging companies to be healthier if the capital structure and loans follow this rule. Comparison of capital debt 4: 1 means that each loan is guaranteed one-fourth equity (0.25), and the Company is more careful in deciding to borrow.

In the interview results above the authors conclude that the drivers of the implementation of the debt equity ratio policy to counteract the practice of thin capitalization in Indonesia are through PMK-169/2015, education, socialization, Request Letter Explanation of data and Clarification to taxpayers who have a ratio above 4: 1, and the initial investment process. 


\section{Effectiveness Analysis of the Implementation of Tax Policies About Instrument Debt Equity Ratio in Increasing Tax Revenues in Indonesia}

Referring to the effectiveness level parameters according to Munir, et al (2004: 151), the evaluation of tax regulations concerning the Debt Equity Ratio instrument to counteract the Thin Capitalization in relation to investment policies and tax revenues in Indonesia can be categorized as the following levels of effectiveness:

a. The level of achievement above $100 \%$ means very effective

b. Achievement rates between $90 \%-100 \%$ means effective

c. The level of achievement between $80 \%-90 \%$ means quite effective

d. Achievement rates between $60 \%-80 \%$ means less effective

e. Achievement rates below $60 \%$ means ineffective

Based on the author's analysis of the data obtained, for the effectiveness of implementing tax policies on instruments of debt equity ratio in increasing tax revenues in Indonesia from 2014 to 2017 the results are less effective. A policy is said to be effective if the activity process reaches its goals and objectives. The greater the output produced towards achieving the objectives and targets specified, the more effective the work process of an organizational unit.

\section{Effectiveness of DER}

The term Thin capitalization is defined as covert capital through loans that exceed the limits of reasonableness. Loans in the context of thin capitalization are loans in the form of money or capital from shareholders or other parties that have a special relationship with the borrowing party. To counter this, the general policy carried out by the government is to set restrictions on the debt to equity ratio (DER). Previously in 1984 the DER 3: 1 policy had been regulated, but in 1985 a letter was issued for the suspension of the policy due to consideration of a business climate that was not supportive. It is suspected that many foreign investors in Indonesia, who finance the operations of their companies, prefer prioritizing loans rather than equity/own capital due to the disparity in tax treatment that is more profitable interest (loan capital rewards) as a deduction from taxable debtors rather than dividends equity income), so that the thin capitalization action can reduce tax revenue. With such a background, the 2015 DER 4: 1 policy was re-issued, where if benchmarked to other countries this is a provision that is very familiar and generally applied. The majority of countries that we can do benchmarks still use fixed ratio based on DER. The Minister of Finance of the Republic of Indonesia issued PMK169/2015 concerning the determination of the Big Ratio of Comparison of Debt and Company Capital for the Calculation of Income Tax, which came into force since the 2016 Tax Year. In the regulation it was stated that the calculation of income tax was determined by the ratio of debt and capital for established taxpayers or domiciled in Indonesia whose capital is divided into shares. Debt magnitude is obtained from the average debt balance in one tax year or part of the tax year, which is calculated based on: i. average debt balance at the end of each month in the tax year concerned; or ii. average debt balance at the end of each month in the relevant tax year.

If viewed from benchmarks in other countries, the provisions of the debt equity ratio for the current implementation of tax policy on the Debt Equity Ratio instrument, none of the speakers from the research authors denied that the DER was sufficient effective in counteracting thin capitalization in Indonesia, tax policy on debt equity ratio instruments issued by the government through PMK-169/2015 concerning Determination of the ratio between Debt and Company Capital for purposes of Income Tax Calculation, the amount 
the ratio between debt and capital is set to a maximum of four to one (4:1) and based on article 7 of this PMK comes into force from the 2016 Tax Year. Consequently, for companies that still have a debt and capital ratio of more than 4 : 1 , the impact on a positive fiscal correction of the loan interest charged.

The regulation regarding the limit of debt interest allowed to be deducted from tax is usually applied to finance the parent company to its subsidiaries in other countries. This has been done by several developed countries as explained by Team Edgar, Jonathan Farrar, and Amin Mawani in their journals entitled Foreign Direct Investment, Thin Capitalization, and the Interest Expense Deduction: A Policy Analysis, namely 5 (five) countries including Australia, Denmark, Germany, Italy and New Zealand have enacted comprehensive restrictions on interest expenses that can be deducted in the context of foreign direct investment (DDTC, 2018).

\section{Aspects of Justice}

The Minister of Finance Regulation No.169/PMK.010/2015 implies that from the side of tax authorities it is good in the sense of applying the principle of consistency in charging interest fees. If the capital is smaller than the loan at a certain level it means the company is not healthy. In my opinion, taxation in charging fees requires the principle of fairness, which means that the burdens that are charged must be in line with the principles of normal business. If there is a fee charged, this fee must be fair. If the company's loan interest is not in proportion to the loan business, then this interest should not be charged because the company is not healthy (so that financial and capital restructuring must be done). Then the interest charged is also not healthy, so it cannot be charged. Approximately like this PMK-169/2015 message in general to do. But from the side of the taxpayer, of course there is a bad thing because usually the company is in liquidity difficulties. Companies that are experiencing liquidity difficulties such as this may not even charge interest fees "only" because they do not meet the debt comparison requirement for their capital. From the aspect of tax justice, such treatment seems unfair.

7. Have tax policies been synergized about DER instruments with investment policies in Indonesia?

In general, we can say that the tax policy regarding DER instruments has not been synergistic with investment policies in Indonesia for the following reasons. First, if the regulations issued by the legislation must have already been harmonized, the consideration is what the impact will be. If it is contrary to investment policy, certainly not. A simple example is taken, namely infrastructure as one that is excluded by the DER provisions. We are arranging investments in the infrastructure sector because we are building a lot and need more funds, so if stipulated DER provisions are likely to be influential, so the steps are excluded from DER. When viewed from PMK-169/2015, there are special industries that are excluded, such as banks, because the business and risk ratio is high and that is not to avoid taxes, but the business is indeed. And those that are excluded from PMK-169/2015 are not at all regulated for DER or in the sense that they are released, the test does not necessarily count the number, it is not so, it requires deep and special testing. In other parts of the country, usually in the treatment of two, namely financial industries and industry in general, he will have two differentiated DERs. In Indonesia, it is preferred for general industries only and others are excluded. Second, because indeed this policy does not distinguish between companies that use this PMK169/2015 and those that do not. All are considered equal and treated equally. Third, 
because it is not efficient for investors considering the scope of the definition of debt and the ratio used is not in accordance with the size of the company's financial health.

\section{Conclusions And Suggestions}

\subsection{Conclusion}

Based on the analysis and evaluation carried out at the Foreign Investment Services Office One Tax Office and the Investment Coordinating Board (BKPM) for 2014 to 2017, the researchers provide conclusions and suggestions as follows:

1. In implementing the tax policy on instrument debt equity ratio, it is quite effective in counteracting the practice of thin capitalization in Indonesia, because the tax policy regarding the debt equity ratio instrument issued by the government through PMK169/2015 concerning Determination of the ratio between Debt and Company Capital for purposes of Income Tax Calculation, the magnitude of the ratio between debt and capital is set at a maximum of four to one (4: 1) and based on article 7 of this PMK-169/2015 comes into force since the 2016 Tax Year. So for companies that still have a debt and capital ratio of more than $4: 1$, which will have an impact on the positive correction of the loan interest charged.

2. Regarding the tax policy regarding the debt equity ratio instrument, it has an indirect influence on investment policies in Indonesia, because the Directorate General of Taxes stipulates that the debt equity ratio has been considered in a macro manner that will not disrupt the business climate and the Directorate General of Taxes strives to ensure that the DER provisions not too close to investors to invest in Indonesia. This provision is made in such a way as not to limit investors but also can eliminate those who use Indonesia as tax avoidance where continuous losses but still impose costs and that is what they want to eliminate.

3. In the implementation of the debt equity ratio policy to counteract the practice of thin capitalization in Indonesia there are inhibiting entities, namely the debt equity ratio concession where the previous provisions from 3:1 to 4: 1, education, socialization and the stages of introduction of PMK-169/2015 concerning Determination of the Amount of Comparison between Corporate Debt and Capital for Income Tax Calculation Requirements and PER-25/PJ/2018 Regarding the Determination of the Amount of Comparison Between Corporate Debt and Capital for Needs of Income Tax Calculation and Procedures for Foreign Private Debt Reporting.

4. Regarding the entity that drives the implementation of the debt equity ratio policy to counteract the practice of thin capitalization in Indonesia through PMK-169/2015, Education, Socialization, and Request Letter Explanation of data and Clarification to taxpayers having ratios above $4: 1$.

\subsection{Suggestions}

With conclusions made by the researchers above, the authors provide suggestions as follows:

1. It is recommended that the Directorate General of Taxes and the Foreign Investment Tax Office One provide more education and outreach to all companies in Indonesia to help them understand PMK-169/2015 and PER-25/PJ/2018 because this regulation has long been suspended and has just been re-established so that the taxpayer considers it as a new 
regulation and the tax authorities are obliged to carry out an audit to reduce indications of reduced state revenues and tax revenues can meet the target.

2. DGT and Tax Office should more often monitor whether the ratio of debt and capital allowances will affect future investments or not, even though it is not only because these provisions affect investment but the provisions of the debt equity ratio have an indirect impact on investment, Good cooperation between DGT and BKPM to monitor and see investment developments is also needed, so that tax policies that should have a major impact on investment in Indonesia can be minimized by these impacts with adjusted studies and regulations. If benchmarked to other countries the ratio of the ratio of capital debt set by the Minister of Finance through PMK-169/2015 is slightly looser and if possible proposed new regulations from OECD countries and world banks to try and consider using alternatives new, namely EBITDA so that it can be adapted to the circumstances of Indonesia besides not hindering investment, nor does it erode more state revenues.

3. There is a need for supervision and inspection of Tax Offices to corporate taxpayers who report their private debt position so that it is easier for Tax Offices to indicate the existence of engineering reporting from taxpayers who will erode tax revenues.

\section{References}

\section{Books :}

[1]. Aritonang, JM. 2008. Perpajakan Internasional Sebagai Materi Studi di Perguruan Tinggi. Bandung: Grasindo.

[2]. Arnold, Brian J. Michael J. 2008. International Tax Primer. New York: Kluwer Law Internasional.

[3]. Barry, Spitz. 1983. International Tax Planning Second Edition. London: Butterworths.

[4]. Crumbley, Larry et al. 1994. Dictionary of Tax Terms. New York: Barrons.

[5]. Darsono dan Ashari. 2010. Pedoman Praktis Memahami Laporan Keuangan (Tips Bagi Investor, Direksi, dan Pemegang Saham). Yogyakarta: Penerbit Andi.

[6]. Darussalam dan Danny Septriadi. 2008. Konsep dan Aplikasi Cross Border Transfer Pricing Untuk Tujuan Perpajakan. Jakarta : Danny Darussalam Tax Center.

[7]. Devas, Nick. 1996. Keuangan Pemerintah Daerah di Indonesia. Jakarta: UI Press.

[8]. Doernberg, R.L. 2016. International Taxation in a Nutshell. Minnesota: West Academic Publisher.

[9]. Easson, Alex. 2004. Tax Incentives For Foreign Direct Investment. Netherlands: Kluwer Law International.

[10]. Gunadi. 2012. Akuntansi Pajak. Bandung: Grasindo.

[11]. -------. 1994. Transfer Pricing Suatu Tinjauan Akuntansi Manajemen dan Pajak. Jakarta: PT Bina Rena Pariwara.

[12]. --------. 2007. Pajak Internasional. Edisi Revisi. Jakarta: Lembaga Penerbit FEUI.

[13]. Hady, Hamdy. 1998. Ekonomi Internasional. Jakarta: Ghalia Indonesia.

[14]. Harahap, Syafri Sofyan. 2010. Analisis Kritis Atas Laporan Keuangan. Jakarta: Rajawali Persada.

[15]. Judisseno, Rimsky K. 2001. Perpajakan. Edisi Revisi. Jakarta: Gramedia Pustaka Utama.

[16]. Kasmir. 2014. Bank dan Lembaga Keuangan Lainnya. Edisi Revisi. Cetakan Keempat Belas. Jakarta: PT.Raja Grafindo Persada.

[17]. Kurniawan, Anang Mury. 2011. Pajak Internasional Beserta Contoh Aplikasinya. Bogor: Ghalia Indonesia. 
[18]. Krugman R. Paul dan Maurice Obsfeld. 1994. Ekonomi Internasional, Teori dan Kebijakan. Jakarta: PT. Raja Grafindo Persada.

[19]. Makmur, Syarief. 2008. Pemberdayaan Sumber Daya Manusia dan Efektivitas Organisasi. Jakarta: PT.Raja Grafindo Persada.

[20]. Mardiasmo. 2004. Akuntasi Sektor Publik. Yogyakarta: Andi Offset.

[21]. ----------. 2013. Perpajakan. Edisi Revisi. Yogyakarta: Cv.Andi Offset.

[22]. Moosa, Imad A. 2002. Foreign Direct Investment: Theory, evidence, and Practice. New York: Palgrave Macmillan.

[23]. Moleong. 2016. Metodologi Penelitian Kualitatif. Edisi Revisi. Bandung: PT. Remaja Rosdakarya Offset.

[24]. Muktar. 2013. Metode Penelitian Deskriftif Kualitatif. Jakarta: GP Press Group.

[25]. Munir, Dasril et al. 2004. Kebijakan dan Manajemen Keuangan Daerah. Yogyakarta: Yayasan Pembaruan Administrasi Publik Indonesia (YPAPI).

[26]. Nazir, Moh. 2011. Metode Penelitian. Jakarta: Ghalia Indonesia.

[27]. Neuman, W.L. 2011. Social Research Methods: Qualitative and Quantitative Approach, 6th ed. Boston: Allyn and Bacon.

[28]. Noor, Henry Faizal. 2014. Investasi, Pengelolaan Keuangan,dan Pengembangan Ekonomi Masyarakat. Edisi Revisi. Jakarta: Mitra Wacana Media.

[29]. Nurmantu, Safri. 2005. Pengantar Perpajakan. Jakarta: Granit.

[30]. Pandiangan, Liberti. 2014. Administrasi Perpajakan. Jakarta: Erlangga.

[31]. Pohan, Chairil Anwar. 2017. Pembahasan Komprehensif Pengantar Perpajakan Teori dan Konsep Hukum Pajak. Edisi Revisi. Jakarta: PT.Mitra Wacana Media.

[32]. -----------. 2017. Manajemen Perpajakan Strategi Perencanaan Pajak dan Bisnis. Edisi Revisi. Jakarta: PT. Gramedia Pustaka Utama.

[33]. --------. 2018. Pedoman Lengkap Pajak Internasional. Konsep, Strategi dan Penerapan. Jakarta:PT.Gramedia Pustaka Utama.

[34]. Rahayu, Siti Kurnia. 2010. Perpajakan Indonesia : Konsep dan Aspek Formal. Yogyakarta: Graha Ilmu.

[35]. Resmi, Siti. 2013. Perpajakan Teori dan Kasus. Edisi 7. Jakarta: Salemba Empat.

[36]. Rosenbloom, David H et al. 2015. Public Administration: Understanding Management, Politics, and Law in the Publik Sector. Eighth Edition. New York: McGraw-Hill.

[37]. Sahni, Pardeep. Etakula Vayunandan. 2010. Administrative Theory. New Delhi: PHI Learning.

[38]. Saragih, Ferdinand D. 2008. Keuangan Internasional. Depok: Departemen Ilmu Administrasi Fakultas Ilmu Sosial dan Ilmu Politik Universitas Indonesia.

[39]. Suandy, Erly. 2008. Perencanaan Pajak. Edisi 4. Jakarta: Salemba Empat.

[40]. Sugiyono. 2014. Metode penelitian kuantitatif kualitatif dan R\&D. Bandung: Penerbit Alfabeta.

[41]. Supramono dan Theresia Woro Damayanti. 2005. Perpajakan Indonesia : Mekanisme dan Perhitungan. Yogyakarta: Andi.

[42]. Suprianto, Edy. 2014. Hukum Pajak Indonesia. Yogyakarta: Graha Ilmu.

[43]. Suharyadi dan Purwanto. 2009. Statistika Untuk Ekonomi Dan Keuangan Modern. Edisi 2 Buku 2. Jakarta: Salemba Empat.

[44]. Syafii, Inu Kencana. 2006. Ilmu Administrasi Publik. Jakarta: Rineka Cipta.

[45]. Wirawan. 2012. Evaluasi:Teori, Model, Standar, Aplikasi, dan Profesi. Depok: PT Raja Grafindo Persada.

[46]. Zain, Mohammad 2008. Manajemen Perpajakan. Edisi 3. Jakarta: Salemba Empat. 


\section{Journals and Other Sources}

[1]. Budiman, Fajar. Analisis Peraturan Anti Penghindaran Pajak Transaksi Thin Capitalization Dalam Hukum Perpajakan Indonesia. Tesis Fakultas Hukum Program Studi Ilmu Hukum Program Pascasarjana Kekhususan Hukum Ekonomi, 2011 January.

[2]. Haufler, Andreas and Marco Runkel. Firms' financial choices and thin capitalization rules under corporate tax competition. 2009. Cesifo Conference Center, Munich.

[3]. Nuraini, Novia Suci dan Marsono. Analisis Faktor-Faktor yang Mempengaruhi Thin Capitalization Pada Perusahaan Multinasional di Indonesia. Jurnal Diponegoro of Accounting Volume 3, 2014 (http://ejournal-s1.undip.ac.id/index.php/accounting).

[4]. Noor, Anissa. Debt To Equity Rule: Thin Capitalization Dalam Perkembangan Investasi di Indonesia. Jurnal Penelitian Hukum Volume 1, 2014 November (https://journal.ugm.ac.id/jph/article/view/19107).

[5]. Rahayu, Ning. Evaluasi Regulasi atas Praktik Penghindaran Pajak Penanaman Modal Asing. Jurnal Akuntasi dan Keuangan Indonesia Volume 7, 2010 June(http://jaki.ui.ac.id/index.php/home/article/view/168).

[6]. Rahayu, Ning. Praktik Penghindaran Pajak oleh Foreign Direct Investment Berbentuk Perseroan Terbatas Penanaman Modal Asing. Jurnal Ilmu Administrasi Negara Volume 10, 2010 July (https://ejournal.unri.ac.id/index.php/JIANA/article/view/1067).

[7]. Ramadhan, Muhammad Rheza dan Riko. The Effect of Thin Capitalization Rule to Corporate Capital Structure Indonesia. Jurnal Manajemen Bisnis dan Inovasi Volume 4, 2017 November (https://ejournal.unsrat.ac.id/index.php/jmbi/article/view/17992).

[8]. Siahaan, Richard Pardomuan Parulian. Analisis Kebijakan Penangkal Praktik Thin Capitalization di Indonesia. Tesis Fakultas Ilmu Sosial dan Ilmu Politik Departemen Ilmu Administrasi Program Pascasarjana Kekhususan Administrasi dan Kebijakan Perpajakan, 2010 June.

[9]. Investasi langsung luar negeri dan perusahaan multinasional. https://speunand.blogspot.co.id/2011/12/investasi-langsung-luar-negeri-dan.html. Accessed on 23 March 2018.

[10]. http://psakindonesia.blogspot.co.id/2014/05/definisi-dalam-psak-7 pengungkapan.html Accessed on 24 March 2018.

[11]. http://www.idx.co.id/ Accessed on 27 March 2018.

[12]. http://bisniskeuangan.kompas.com/read/2016/04/14/083000826/Apa.Perbedaan.Praktik.Penghindar an.Pajak.dan.Penggelapan.Pajak. Accessed on 15 February 2018.

[13]. https://finance.detik.com/berita-ekonomi-bisnis/d-3169957/menkeu-2000-perusahaan-asing-di-ritak-bayar-pajak-selama-10-tahun. Accessed on 15 February 2018. 